\title{
FORUM
}

\section{Doppler Correction for Surface Movement}

\author{
from Wing Commander D. F. H. Grocott, A.F.C.
}

A DOPPLER navigation system measures velocity relative to the surface of the Earth. If the surface is moving, as for example when flying over an ocean, the doppler will indicate a false ground-speed and/or drift, according to the direction of surface movement.

Trials carried out by the Experimental Navigation Division of the Aeroplane and Armament Experimental Establishment at Boscombe Down show that there is a positive correlation between doppler system error and the surface wind direction when flying over the sea in an aircraft which has an accurate heading reference system. The analysis of all data is by no means complete, but as the spread of errors is so small it is thought that users of doppler navigation systems may wish to see the trend of results and to accept a few simple rules to compensate for the surface movement.

The value of the surface movement for a doppler equipment having a I per cent correction for spectrum distortion is about $3 \mathrm{kt}$. for a surface wind velocity of $10 \mathrm{kt}$., $4 \mathrm{kt}$. for a wind velocity of $18 \mathrm{kt}$., $5 \mathrm{kt}$. for a wind velocity of $30 \mathrm{kt}$. and $6 \mathrm{kt}$. for a wind velocity of $50 \mathrm{kt}$. or more. The cardinal rule is that the doppler navigation system will indicate a position upwind of the correct position.

Clearly there is little point in applying an across-track correction of say $6 \mathrm{kt}$. when flying in a Boeing 707 at a speed of $500 \mathrm{kt}$., if the compass has an error of $2^{\circ}$, but doppler users may wish to apply a correction to the ground-speed component of say $-6 \mathrm{kt}$. when the surface wind is on the nose and $+6 \mathrm{kt}$. when the surface wind is dead astern. Those lucky operators who have an automatic sextant may wish to refine their electronic dead reckoning position by applying the surface movement vector downwind from the indicated doppler.

\section{Notes on Heavy Weather in the Atlantic I960 and North Sea 1961}

\author{
from David H. Lewis, M.в., сн.в.
}

The following notes, from one of the contestants in the single-handed transatlantic race 1960 , will be of great interest to a number of people concerned with wind and weather observations and the performance of small boats in heavy weather. Dr. Lewis's track in 1960 was by the great circle from Plymouth to New York, from New York up to St. John's, Newfoundland, and then back across the Atlantic to Lerwick in the Shetlands. 
THE following observations of wind and weather were made aboard the $25-\mathrm{ft}$., 5 -ton sloop Cardinal Vertue, single handed in 1960 and with a companion in 1961. Wind speeds by hand instruments were checked with Daily Weather Reports when possible and (for 1961) against the B.B.C. forecasts.

Sailing to New York, the wind only briefly reached gale force on 26 June, 16 July and 22 July. However, on $3 \circ$ July when I was in $4 \mathrm{I}^{\circ} 32^{\prime} \mathrm{N} .67^{\circ} \circ 7^{\prime} \mathrm{W}$. the centre of tropical storm Brenda passed some 50 to 100 miles NW. of me the evening and early hours of 31 July. I was in the eastern semi-circle and experienced gale force SE. winds which veered SW. and dropped to a calm before morning. The sea throughout was confused and the motion exceedingly violent. At first I could make some progress to windward close reefed. I then attempted to heave-to under close reefed mainsail but violent flogging which made me fearful for the mast made me lie a-hull. I was sick and exhausted. The storm passed by quickly.

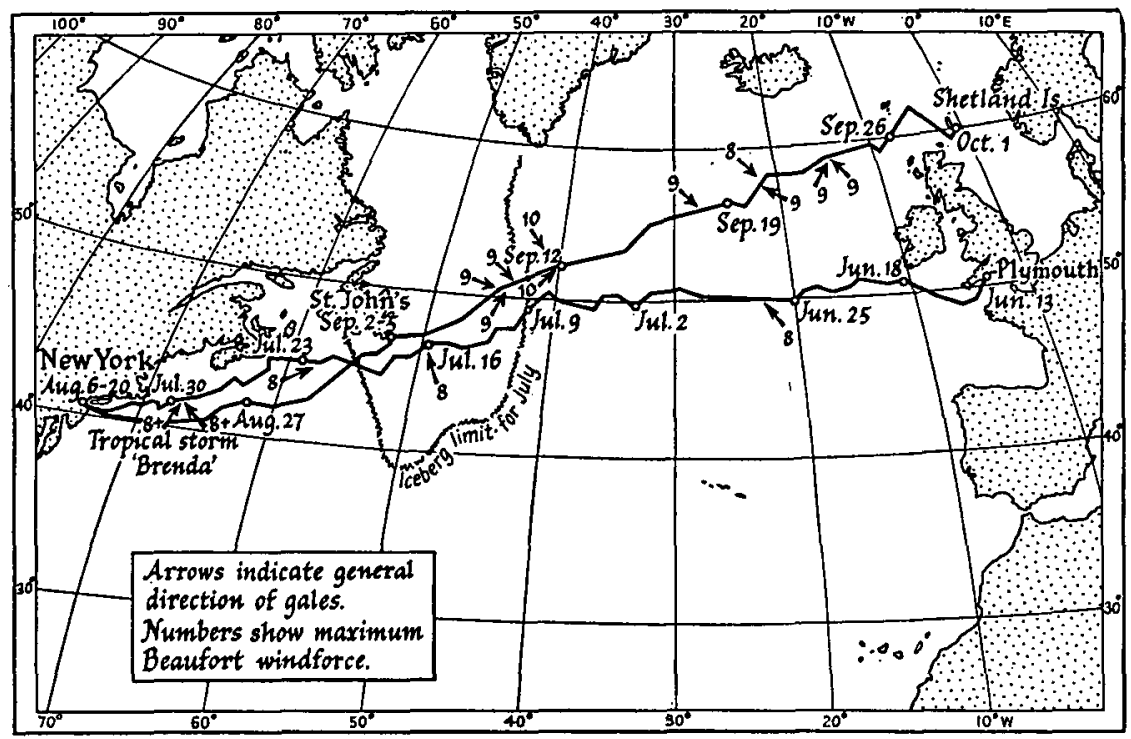

FIG. 1. Cardinal Vertue's routes

The U.S. Weather Bureau Report states that at 1700 E.D.T. on the 30 th, Brenda was centred in $42^{\circ} \circ 3^{\prime} \mathrm{N} .72^{\circ} \circ 7^{\prime} \mathrm{W}$., or 80 miles west of Boston, and moving NE. at 28 m.p.h. Highest wind was 40 m.p.h. with gusts of 60 m.p.h. within 200 miles of centre in eastern semi-circle.

During the voyage from St. John's, Newfoundland to Lerwick, Shetland Isles (5 September-I October 1960) I experienced gale force winds on six occasions. The D.W.R.'s of the British Meteorological Office and reports from O.W.S. India for 21 September have helped fill in the picture.

8 September. At noon I was in $50^{\circ} 35^{\prime} \mathrm{N} .45^{\circ}$ i $5^{\prime} \mathrm{W}$. The wind was SW. force 9 (49 m.p.h.), the glass $996 \mathrm{mb}$. A warm front extended from Nova Scotia across Newfoundland to an area of low pressure halfway to Cape Farvel. The nearest ship was 100 miles north of me and reported winds of force 8 (37 knots) and a barometer reading of 1004 . The waves were in long lines of majestic marching seas. When the wind reached force 8 at 10.00 , I estimated the height of the seas 
at $1 \circ \mathrm{ft}$., and $150 \mathrm{ft}$. long. I ran under staysail, steering with the vane with the wind on the quarter. At noon when the wind had reached 49 m.p.h. and again at I 2.30 I was pooped. On the second occasion all the brass fastenings of the canvas dodger sheered. At I 300 the wind was 50 m.p.h. The staysail sheet pulled a fairlead out of the deck. I lowered sail. The seas were curling over and breaking (with considerable shock whenever they broke over the ship).

I streamed 20 fathoms of warp in a bight and attempted to steer before the wind. The ship at once became almost unmanageable and ran across the seas in the trough. When I did succeed in steering before the seas, each breaking wave would carry the warp alongside. So at i 530 I lay a-hull and so remained for five and a half hours. The ship tended to fall off when a-hull, but to 'give' before the breaking seas. She would be hove over up to $50^{\circ}$ as one crashed over her and would slide sideways or spin around.

9 September. My noon position was $51^{\circ} \circ 7^{\prime}$ N. $43^{\circ} 33^{\prime}$ W., when a (NW.) gale blew up during the afternoon and reached force 9 (49 m.p.h.). No ship was within several hundred miles and the nearest weather ship was $45^{\circ}$ miles ENE. She reported moderate winds but seas $17 \frac{1}{2} \mathrm{ft}$. high, an indication of a gale in the area. Away to the NW. of my position Ocean Weather Ship B was logging I 9 -ft. waves, an indication of the gale that was approaching; it reached me on I I September. There was a confused cross sea in the i september gale, quite different from the conditions the day before. The yacht was repeatedly broachedto and thrown aback both before and after lying a-hull (i 2 hours). This time there was a tendency to luff.

I I September. By noon a new area of low pressure had formed not far to the $\mathrm{NW}$. of me and a fresh front was approaching. My position was $52^{\circ} 20^{\prime} \mathrm{N}$. $39^{\circ} 50^{\prime} \mathrm{W}$., 150 miles west of Ocean Weather Ship C, which was at $52^{\circ} 50^{\prime} \mathrm{N}$. $35^{\circ} 30^{\prime} \mathrm{W}$. At noon this O.W.S. reported a SW. gale force 9 ( 42 knots) and seas $14 \mathrm{ft}$. high. I was also logging a SW. gale, force 9, at noon. By 1800 the waves at the O.W.S. had reached $17 \frac{1}{2} \mathrm{ft}$. in height. I ran under staysail until early afternoon when first a fairlead, then a sheet parted. I then steered before the seas for a while under bare poles. The yacht 'surfed' on the seas, water spouting high each side, then curling over and pouring into the cockpit, whence it arched out over the stern. It was partly 'bucked out' by the motion as well. The Smiths indicator read 8 knots as she surfed. I then lay a-hull, the ship tending to luff. Later in the gale she fell off before the seas.

Between $16{ }_{1} 5$ and 1830 the wind reached $58 \mathrm{~m}$.p.h., force ro. The whole sea was white, the waves seemed flattened and the tops to be blown right off. After the wind decreased again to force 9, the sea continued to get up and to break with more fury. The impact was so fearful when those seas broke over the yacht that I feared she would be stove-in.

I shackled the sea anchor warp to a half-inch diameter wire strop which I had previously led round the stern. This seemed ineffective in holding the yacht end on. In fact she seemed to be held up to the pounding. Sometimes waves would dash across the line of the seas. I was too tired to attempt to steer or to take in the drogue. The wind quickly moderated but I lay to the sea anchor all night. In the morning I found the wire warp chafed half through, the covering board split and cleats torn from the stern. At Lerwick we found that the paint had cracked where the transom had been pulled bodily backwards.

18 September. A NW. gale 48 m.p.h. (force 9). The D.W.R. showed a cold front having just passed my position. 
20-2 I September. My noon positions were $57^{\circ} 25^{\prime}$ N. $21^{\circ} 50^{\prime} \mathrm{W}$. and $58^{\circ} 08^{\prime} \mathrm{N}$. $20^{\circ} 24^{\prime} \mathrm{W}$. respectively. O.W.S. was at $59^{\circ} \mathrm{N}$. $19^{\prime} \mathrm{W}$., approximately 150 and 90 miles NE. of my two positions. A low pressure system with winds of force 9 had appeared to the SW. on the i 8 th and moved NE. to cross directly over my position on the $20-2$ Ist.

On the 2 oth an ESE. gale began. At noon a ship to the southward reported a wind speed of 37 knots (force 8) though at the time I was logging force 7 . During the early evening the wind reached force 9 for a time. In the night the wind dropped to a light breeze for three hours, the glass remaining steady at $992 \mathrm{mb}$. I had been able to keep going to windward under close reefed main and reefed staysail until the wind reached force 9. I had then hove-to under close reefed main alone. The gale recommenced from the NW. reaching force 9, but moderating before noon. A ship north of me was still experiencing force 8 ( 37 knots) winds at noon, but O.W.S. I, now 90 miles NE. of me was logging the same wind strength as I was ( 28 knots) force 7 , westerly. This had been preceded at the O.W.S. by a SE. gale of force 8 which blew from midnight to o6 I 5 . The sea at noon was confused and $1_{3} \mathrm{ft}$. high (O.W.S.) I estimated the seas from the rigging as $14 \mathrm{ft}$. high also at noon. In both cases the wind was force 7 , at the time.

23 September. In $58^{\circ} 48^{\prime} \mathrm{N}$. $14^{\circ} 50^{\prime} \mathrm{W}$. a gale began in the SE., blowing at force 8 and later veering to SW., when from 1800-2100 it blew at force 9. The sea in this gale was remarkably even, considering the veer. I was able to keep going, first under reefed main and reefed staysail and after the veer under reefed staysail alone. The yacht steered by the vane but was frequently broached-to or thrown bodily a-back. The D.W.R. shows that the centre of a depression passed approximately over my position about noon on the $23 \mathrm{rd}$. Next day a ship to the NE. which was near the centre of the disturbance at its new position, reported force 9 winds.

4-5 July 1961 . In sea area Fisher in the North Sea bound south from Stavanger to the Thames, noon position $56^{\circ} 35^{\prime} \mathrm{N} .5^{\circ} 15^{\prime} \mathrm{E}$. On the $4^{\text {th a severe (force 9) }}$ northerly gale was forecast. At $083^{\circ}$ on the 4 th the gale came on suddenly in a line of white water at $4 \mathrm{I}$ m.p.h. (force 8). I lay a-hull for fourteen hours. At I 130 it was blowing force 9 (48 m.p.h.); seas confused; period 7 secs.

In spite of the helm being lashed down the ship tended to fall off. We got underway at 2230 . The wind was then force 7 . It blew at force 7 , and sometimes force 8 next day. In the early hours of the following morning (6th) the seas measured from the rigging were still $8-9 \mathrm{ft}$. Though this gale occurred in soundings as little as sixteen fathoms, the seas did not seem steeper than in the Atlantic gales. They seemed smaller, but this was purely a subjective impression.

Discussion. In each gale the wind seemed to behave differently and so did the yacht. I did not know whether she escaped serious damage because of, or in spite of, any action on my part; nor did I realize the power of the waves until something gave way. A deep-keel yacht with outside ballast, a self-draining cockpit and everything battened down, is self-righting. There seemed no danger in broaching-to or being thrown a-back in such a vessel.

I would have gravely over-estimated the height of the seas from the cockpit; only from the rigging was it possible to be accurate. Figures from several standard works used by yachtsmen give high figures for the heights of waves in gales. However, the fetch is taken as unlimited and the time the gale had been blowing also unlimited. 
I never experienced such conditions, as the fetch was from the centre of the disturbance causing the gale-often 200-300 miles and the gale commonly changed direction after twelve hours or so.

Dr. G. E. R. Deacon in a personal communication says he would expect waves whose highest third would average $12 \mathrm{ft}$. and maximum 18 , with a wind of 30 knots (force 7). This was about my experience (see 20-2 I September) allowing for the rather complex conditions.

Erroll Bruce in Deep Sea Sailing gives tables of wave heights, most of whose material, he tells me, is from an Admiralty paper of 1945 . He mentions that Rachael Carson in The Sea Around Us concludes that 'Waves higher than $25 \mathrm{ft}$. from trough to crest are rare in any ocean ... mariners stubbornly describing higher waves'.

My own limited experience is in line with Erroll Bruce's tables. The greatest mean height of waves recorded by an O.W.S. in my vicinity was $17 \mathrm{ft}$. 6 inches. This would give occasional maximum waves of $24 \mathrm{ft}$.

What to do in a gale? It is probably safe to lie a-hull in a well found yacht up to force 9-10. In stronger winds the vessel may be burst asunder or rolled over. I fortunately had no experience of these conditions, but would think that if a change of helmsmen were available, steering dead before the wind with warps astern, might be best, when running in gales. I do not think the shape of the boat's stern is important, but the whole of her underwater lines determine how she lifts and how she runs. 